\title{
Design and operating rules in the essential requirements - ergonomic aspects
}

\author{
Adam Górny* \\ Poznań University of Technology, Faculty of Management Engineering, Chair of Ergonomics and \\ Quality Management, ul. Strzelecka 11, room 318c, Poznan, Poland
}

\begin{abstract}
Technical equipment should satisfy safety specifications and ergonomic requirements throughout its usable life. The ergonomic requirements applied in the design process should be perceived as an integral part of the body of requirements intended to ensure the safest possible operation of technical equipment. Ergonomic criteria highlight the necessity to adjust technical equipment to the needs of users so as to avert any identified hazards. The design safety requirements defined as essential should also be seen as guidelines for the development of conditions which ensure the effective performance of work. Such requirements must account for ergonomic criteria, which need to be seen as a mandatory. The article refers to the need to take into account ergonomic requirements when designing machines and technical devices. Examples of such requirements and the possibility of verifying their implementation are indicated.
\end{abstract}

\section{Introduction}

Any technical equipment found in the workplace is required to satisfy the safety standards stipulated in applicable laws. The rules that are essential for the safe operation of such equipment have been laid down in relevant European Union directives. The very core of safety requirements can be found in the so-called New Approach Directives and New Legislative Framework Directives. Among laws on machinery and technical equipment, the most central requirements are laid down in the Machinery Directive 2006/42/EC. The companies that follow its provisions achieve compliance with essential safety requirements [1]. A vital part of such requirements are rules designed to ensure that workers work in comfort and achieve efficiency and effectiveness in performing their tasks. Such rules include the ergonomic criteria that link technical solutions with operator characteristics, referred to as the human factor. Conformity with these rules in the design process should be considered mandatory, as it affects compliance with the essential requirements. The ergonomic requirements that are recognised and adhered to should be seen as an integral part of the design requirements aimed at ensuring the safer use of technical equipment. Once ergonomic requirements have been recognised as crucial, it becomes evident that it is essential to adapt technical equipment to the individual characteristics of users [2-9].

${ }^{*}$ Corresponding author: adam.gorny@put.poznan.pl 


\section{Essential requirements and ergonomic criteria in the design process}

One of the key responsibilities of machinery and technical equipment designers is to adhere to the European safety requirements designed to ensure that equipment is operated without endangering any persons involved. This effort should be seen as vital for ensuring effective work performance $[6,10]$ and, as such, as a prerequisite for compliance with the essential requirements $[11,12]$. In identifying and complying with applicable requirements, due account should be taken of any unique characteristics of specific machines and technical equipment, so as to afford the user the required level of protection against any existing risks.

Solutions applicable to production work have been defined in the New Approach Directives, with detailed rules set forth in the harmonised standards, which offer technical solutions designed to achieve compliance with the essential requirements $[12,13]$. The key design requirements are to ensure safe and proper performance of work by human operators $[13,14]$. These requirements apply to all areas susceptible to hazards occurring during operation, maintenance and/or repairs. In particular, they concern the design and operation of controls and control systems, guidelines for regular and emergency start-ups and shutdowns, protection against hazards caused by ejected objects and gas and vapour emissions, protection against moving parts, and protection against frostbites, burns, fire, explosions and electric shocks $[11,12,15]$. The essential requirements that account for the functioning of humans during the operation of technical equipment define the scope of application of ergonomic principles to machinery and technical equipment design. By adhering to design principles that are based on ergonomic guidelines, it is possible to ensure that $[14,16,17]$ :

- Human operators work in concert with their machinery,

- Equipment maintenance personnel work well together,

- Psychosocial requirements governing the use of technical equipment are properly complied with,

- Human operators are enabled to take risk-mitigation measures.

In all of the above activities, people are central and should be provided with an environment that is adequate to their needs. Some of the design areas accounted for in the essential requirements are presented in Table 1.

Table 1. Essential requirements based on ergonomic design criteria that are essential for ensuring safety during the operation of machinery and technical equipment (examples) [11, 12, 18].

\begin{tabular}{|l|l|}
\hline \multicolumn{1}{|c|}{$\begin{array}{c}\text { Scope of } \\
\text { requirements }\end{array}$} & \multicolumn{1}{c|}{ Requirement description } \\
\hline Main ergonomic requirements \\
\hline Ergonomics & $\begin{array}{l}\text { Under the intended conditions of use, the discomfort, fatigue and physical } \\
\text { and psychological stress faced by the operator must be reduced to the } \\
\text { minimum possible, taking into account ergonomic principles such as: } \\
\text { - allowing for the variability of the operator's physical dimensions, strength } \\
\text { and stamina, } \\
\text { - providing enough space for movements of the parts of the operator's body, } \\
\text { - avoiding a machine-determined work rate, } \\
\text { - avoiding monitoring that requires lengthy concentration, } \\
\text { - adapting the man/machinery interface to the foreseeable characteristics of } \\
\text { the operators. }\end{array}$ \\
\hline Indirect ergonomic requirements \\
\hline Lighting & $\begin{array}{l}\text { Machinery must be designed and constructed so that there is no area of } \\
\text { shadow likely to cause nuisance, that there is no irritating dazzle and that } \\
\text { there are no dangerous stroboscopic effects on moving parts due to the } \\
\text { lighting. }\end{array}$ \\
\hline
\end{tabular}




\begin{tabular}{|l|l|}
\hline \multicolumn{1}{|c|}{$\begin{array}{c}\text { Scope of } \\
\text { requirements }\end{array}$} & \multicolumn{1}{c|}{ Requirement description } \\
\hline Seating & $\begin{array}{l}\text { The operator's seat must enable him to maintain a stable position. } \\
\text { Furthermore, the seat and its distance from the control devices must be } \\
\text { capable of being adapted to the operator. }\end{array}$ \\
\hline Control devices & $\begin{array}{l}\text { Control devices must be: } \\
\text { - designed in such a way that the movement of the control device is } \\
\text { consistent with its effect, } \\
\text { - made in such a way as to withstand foreseeable forces; particular attention } \\
\text { must be paid to emergency stop devices liable to be subjected to considerable } \\
\text { forces. } \\
\text { Machinery must be fitted with indicators as required for safe operation. The } \\
\text { operator must be able to read them from the control position. }\end{array}$ \\
\hline $\begin{array}{l}\text { Guards and } \\
\text { protective devices }\end{array}$ & $\begin{array}{l}\text { Guards and protective devices must: } \\
\text { - cause minimum obstruction to the view of the production process. }\end{array}$ \\
\hline Means of access & $\begin{array}{l}\text { Handholds and steps must be designed, constructed and arranged in such a } \\
\text { way that the operators use them instinctively and do not use the control } \\
\text { devices to assist access. }\end{array}$ \\
\hline $\begin{array}{l}\text { Information and } \\
\text { information } \\
\text { devices }\end{array}$ & $\begin{array}{l}\text { The information needed to control machinery must be provided in a form that } \\
\text { is unambiguous and easily understood. It must not be excessive to the extent } \\
\text { of overloading the operator. }\end{array}$ \\
\hline $\begin{array}{l}\text { The position of } \\
\text { the driver's seat }\end{array}$ & $\begin{array}{l}\text { Visibility from the driving position must be such that the driver can, in } \\
\text { complete safety for himself and the exposed persons, operate the machinery } \\
\text { and its tools in their foreseeable conditions of use. }\end{array}$ \\
\hline $\begin{array}{l}\text { Control devices in } \\
\text { control systems }\end{array}$ & $\begin{array}{l}\text { Where there are pedals, they must be so designed, constructed and fitted as to } \\
\text { allow safe operation by the driver with the minimum risk of incorrect } \\
\text { operation. They must have a slip-resistant surface and be easy to clean. }\end{array}$ \\
\hline
\end{tabular}

To create a safe working environment that is well aligned with ergonomic requirements, it is crucial to have thorough knowledge of the physical and mental capabilities of humans and the reliability of technical systems [1, 19]. To account for existing factors in the environment, one should examine both the design and operational aspects of any solutions in place [20]. This is done with a view to combining human-related and technical requirements. Poorly designed technical equipment will inevitably contribute to greater fatigue, cause work-related health conditions and occupational diseases and decrease productivity. On the other hand, optimal working conditions will enable and motivate employees to raise productivity. The former is particularly true where the use of machines exceeds people's adaptive capabilities, adversely affecting work performance. Ergonomic requirements can be used to verify whether technical equipment modifications meet user needs and expectations. As such, they play a key role at all stages of technical equipment use. When embracing ergonomic criteria in the design process and specifying the characteristics of the environment in which operational activities will be performed, emphasis should be placed on minimising workloads by $[12,13,21]$ :

- Taking into account the anatomical diversity of workers and their individual capabilities,

- Providing sufficient space to allow works to move around unimpeded in the workplace,

- Ensuring that each individual machine can go through its entire range of motion,

- Enabling the surveillance of equipment operation without the need to maintain focus for excessively prolonged periods,

- Enabling effective two-way exchange of information between the operator and the machine being operated.

By incorporating ergonomic requirements into the design process, hazards and untoward factors can be reduced while employees are afforded opportunities for all-around psychological and social improvement. 


\section{The application of essential ergonomic requirements}

\subsection{The role of ergonomic requirements}

In order to function effectively, any business organisations, including those that rely on technical equipment, need to adopt technologies and solutions that will help them improve work processes and increase safety. To reduce to a minimum the impact of technicalequipment-related hazards on workers, companies should adopt solutions that will enable workers to use tools and other technical equipment in a hazard-free fashion. An inextricable part of such solutions are ergonomic requirements that define people's functioning in the work environment [16]. The human factor is an integral part of the design process [15]. The solutions employed should ensure the elimination of threats to workers' life and health, a minimal biological cost of labour, adequate efficiency, working comfort, and workers' satisfaction with their performance $[11,12,22]$. Thus, workplace fit-out should be adapted to the physical and psychophysical characteristics of man. To ensure complete safety during work performance and properly design work environments, employers need to broadly examine all issues that affect quality improvements in such environments. To that end, it is vital to employ ergonomic requirements that improve the work environment with an eye to satisfying social expectations and achieving the expected financial goals. Ergonomic requirements support the design process helping to increase human capabilities [19]. Frequently, it is also essential to modify workplace equipment to the individual characteristics of users [13]. Such modifications should additionally encompass factors identified as ergonomic risks [1].

\subsection{Guidelines for audits of existing ergonomic requirements}

As they audit any solutions in place, employers verify their current safety status and identify such environment-design options that will enable them to use technical equipment without endangering employees [20, 23]. The audits must produce clear indications on whether technical equipment can be operated safely. A sample scope of requirements adopted for such audits is given in Table 2 .

Table 2. Scope of ergonomic compliance audits.

- Have the conditions and environment in which machinery and technical equipment will be
operated been considered in selecting safety solutions and measures?
- Do the safety solutions and measures in place account for workers' adaptive capabilities?
- Do the adopted solutions and improvement measures lower risk levels?
- Are the solutions in place certain not to generate additional risks and/or untoward factors?
- Do the organisation's solutions optimally account for the expected conditions of equipment
operation and equipment service life?
- Are the solutions in place effective in preventing unacceptable risks?
- Is it possible to perform work efficiently, i.e. do the solutions and security measures in place
not impede the efficient performance of work?
- Do the solutions in place afford effective protection against hazards throughout the expected
machine life under all identifiable operating conditions?
- Do the solutions in place additionally afford protection against hazards resulting from
abnormal behaviours of machine and technical equipment users?

To ensure worker comfort while operating machines, it is also paramount to apply assessment criteria that will help adjust solutions to the individual characteristics of potential users $[2,13,16,24]$. In the assessment process, ergonomic requirements, including the adaptation of tools, machines, the environment and working conditions to the anthropometric and 
psychophysical characteristics of humans, are highly critical $[12,14,24]$. As a final outcome, work should be performed efficiently, effectively and safely at a relatively low biological cost.

To ensure that work can be performed effectively, companies need to embrace, in their design process, ergonomic criteria that define the extent of adjustments needed to make their solutions compatible with user needs [22]. The meaning of such criteria in the design process that is compliant with EN ISO $12100[13,15]$ is presented in Table 3.

Table 3. The role of ergonomic criteria and requirements incorporated into the design process.

\begin{tabular}{|l|l|}
\hline \multicolumn{1}{|c|}{ Stage of design process } & \multicolumn{1}{|c|}{$\begin{array}{c}\text { Aim of using human-factor-related ergonomic criteria and } \\
\text { requirements }\end{array}$} \\
\hline $\begin{array}{l}\text { Identification of hazards } \\
\text { and untoward factors } \\
\text { occurring during the use of } \\
\text { machinery and equipment }\end{array}$ & $\begin{array}{l}\text { - to identify irregularities that reduce performance efficiency, } \\
\text { - to identify irregularities that produce untoward factors, } \\
\text { - to determine the impacts of individual characteristics of persons } \\
\text { entering the workplace and the tasks they perform }\end{array}$ \\
\hline $\begin{array}{l}\text { Verification of normative } \\
\text { requirements }\end{array}$ & $\begin{array}{l}\text { - to identify standards that account for such human-related aspects } \\
\text { of design as are of significance for the effective operation of } \\
\text { machinery and equipment, } \\
\text { - to identify requirements affecting the efficiency of use of } \\
\text { technical equipment, } \\
\text { - to identify such optional requirements for increasing the scope } \\
\text { and level of protection as account for the individual characteristics } \\
\text { of machinery and equipment users }\end{array}$ \\
\hline $\begin{array}{l}\text { Assessment of the risk that } \\
\text { the selected solutions may } \\
\text { compromise safety and the } \\
\text { ability to work effectively }\end{array}$ & $\begin{array}{l}\text { - to highlight risks affecting persons in the zones of impact of } \\
\text { particular equipment, } \\
\text { - to assess the impact of irregularities on the potential for effective } \\
\text { worker functioning in work environment }\end{array}$ \\
\hline $\begin{array}{l}\text { Elimination or mitigation } \\
\text { of risks factor impacts }\end{array}$ & $\begin{array}{l}\text { - to identify solutions that mitigate risk factor impacts, } \\
\text { - to incorporate the criteria related to equipment use into the } \\
\text { process of minimising risk impacts }\end{array}$ \\
\hline $\begin{array}{l}\text { Supervision over risk } \\
\text { reduction }\end{array}$ & $\begin{array}{l}\text { - to ensure supervision over risk reduction with proper account } \\
\text { taken of the characteristics of individual equipment users }\end{array}$ \\
\hline $\begin{array}{l}\text { Consistent achievement of } \\
\text { required safety levels }\end{array}$ & $\begin{array}{l}\text { - to enable the recognition of the significance of human (user) } \\
\text { related requirements in the design process }\end{array}$ \\
\hline
\end{tabular}

\section{Conclusion}

In performing occupational activities, people are exposed to the adverse influence of work environment factors and components. As a result, the potential for accidents is increased. To avert the risks that arise during the operation of machinery and equipment, companies need solutions that mitigate the negative impacts of such risks on workers' ability to function and perform work. In a technological environment, the safe performance of work is ensured by adopting ergonomic requirements that are helpful in eliminating the harmful impacts of irregularities on humans. Compliance with such requirements can be achieved by adopting ergonomic design criteria [21]. To comply with ergonomic criteria, organisations must recognise the psychophysical and anthropometric characteristics of users that are crucial for mitigating the impact of hazards and improving the performance of production tasks. Such solutions help either eliminate or minimise such threats and irregularities as affect the conditions in which operators use equipment and carry out work. The ergonomic requirements considered during the design process should be seen as integral parts of the requirements intended to ensure the safe operation of technical equipment. Therefore, the need to verify their implementation results. Ergonomic criteria may be viewed as providing indications of the extent to which technical equipment has been adjusted to the needs of users, 
i.e. operators and engineering and maintenance personnel. They are an important aspect of conformity the design process with technical requirements defined on the basis of harmonization law.

\section{References}

1. Y. Chinniah, B. Aucourt, R. Bourbonnière, Safety Science 93, 152-161(2017)

2. J. N. Czerniak, Ch. Brandl, A. Mertens, IFAC-PapersOnLine 50(1), 1378-1383 (2017)

3. A. Górny, MATEC Web of Conferences 137, no 03005 (2017)

4. M. Hassall, T. Xiao, P. Sanderson, A. Neal, International Encyclopedia of the Social \& Behavioral Sciences (Second Edition), 297-305 (Elsevier, 2015)

5. J.-H. Lin, A. Kirlik, X. Xu, Applied Ergonomics 66, 179-181 (2018)

6. I. Oygür, Design Studies 54, 23-49 (2018)

7. M. Butlewski, M. Jasiulewicz-Kaczmarek, A. Misztal, M. Sławińska, M., Proceedings of the European Safety and Reliability Conference (ESREL 2014), 1101-1106 (2015).

8. A.M. Lasota, K. Hankiewicz, Occupational Safety and Hygiene, SHO 2016, 261-264, (Portuguese Society of Occupational Safety and Hygiene (SPOSHO), Guimarães, 2016).

9. A.M. Lasota, K. Hankiewicz, Proceedings of the 2016 Int. Conference on Economics and Management Innovations, 272-278 (2016).

10. A. Górny, Occupational Safety and Hygiene, SHO 2013, 164-165, (Portuguese Society of Occupational Safety and Hygiene (SPOSHO), Guimarães, 2013)

11. Guidance on the application of the essential health and safety requirements on ergonomics set out in section 1.1.6 of Annex I to the Machinery Directive 2006/42/EC, http://ec.europa.eu/growth/ sectors/mechanical-engineering/machinery, accessed 14.12. 2017

12. Guide to application of the Machinery Directive 2006/42/EC (Edition 2.1 - July 2017, Update of 2nd Edition), European Commission, Directorate-General for Internal Market, Industry, Entrepreneurship and SMEs (2017)

13. A. Górny, CCIS 435, 449-454 (2014)

14. F. Nachreiner, P. Nickel, I. Meyer, Safety Science 44(1), 5-26 (2006)

15. EN ISO 12100:2010, Safety of machinery. General principles for design. Risk assessment and risk reduction

16. K. Springer, A. Górny, Foundations of Control and Management Sciences 11, 117-126 (2008)

17. I. Sutton, Plant Design and Operations (2nd Edition), 439-463 (Elsevier, 2017)

18. Directive 2006/42/EC of the European Parliament and of the Council of 17 May 2006 on machinery, and amending Directive 95/16/EC (recast), OJ L 157, 9.6.2006, 24 - 86, as amended

19. J.R. Wilson, Applied Ergonomics 45(1), 5-13 (2014)

20. A. Górny, B. Mrugalska B, CCIS 374, part II, 494-49 (2013)

21. J.S. Bradley, Applied Ergonomics 34(1), 23-28 (2003)

22. M. Hietikko, T. Malm, J. Alanenb, Reliability Engineering \& System Safety 96(7), 767774 (2011)

23. S. Aromaa, K. Väänänen, Applied Ergonomics 56, 11-18 (2016)

24. E. Bluff, Safety Science 66, 27-35 (2014) 